\title{
Hogyan csökkent a császármetszések aránya a debreceni Szülészeti Klinikán a koronavírus-pandémia alatt?
}

\author{
Deli Tamás dr. - Lampé Rudolf dr. - Juhász Alpár Gábor dr. \\ Kovács Tamás dr. - Daragó Péter dr. - Bacskó György dr. - Török Olga dr. \\ Debreceni Egyetem, Általános Orvostudományi Kar, Szülészeti és Nőgyógyászati Intézet, Debrecen
}

Bevezetés: Az új koronavírus (SARS-CoV-2) okozta pandémia számos változást eredményezett életünk minden területén, így a debreceni Szülészeti és Nőgyógyászati Klinikán is.

Célkitưzések: A koronavírus-járvány többek között a terminus körüli elektív szülésindukciók gyakorlatának megváltoztatását igényelte. A bevezetett új szakmai eljárásrendeknek, járványügyi intézkedéseknek, a megyei kórházi funkciót ellátó debreceni Kenézy Kórház Szülészeti Osztálya és a Szülészeti Klinika összevonásának, illetve a megváltozott jogi környezetnek a szülészeti ellátásra kifejtett együttes hatásait elemezzük.

Módszerek: Helyi protokollokat és részletes eljárásrendeket készítettünk és vezettünk be. 1. Szülésindukció. 2. Szülésindukció cervixérlelést igénylő esetekben. 3. A szülés módjának megválasztása előzményi császármetszés után. 4. A császármetszés utáni hüvelyi szülést támogató, terminus körüli gondozási protokoll. A protokollok bevezetését követő első 9 hónap szülészeti mutatóit (szülésszám, császármetszések aránya, perinatalis kimenetel, szülésindukciók aránya és sikeressége) vizsgáltuk és hasonlítottuk össze a megelőző időszak debreceni adataival, illetve az országos szülészeti mutatókkal.

Eredmények: Klinikánkon a császármetszés aránya 2020-ban 33,5\%-ra csökkent, a protokollok bevezetése óta pedig 30,7\%, miközben a 2020. évi magyarországi arány 40,3\%. Az összes szülés 20\%-a volt 2020-ban szülésindukció, melyek közül 74\% végződött hüvelyi szüléssel, míg ugyanez 2019-ben 11\% indukcióból 47\%-nak adódott. A havi szülésszám 2020. január és 2021. január között folyamatosan emelkedett (250-ről 450-re), a havi császármetszési arány pedig 41\%-ról 25\%-ra csökkent. Mindezen változások mellett 2019-ról 2020-ra csökkent mind a perinatalis mortalitás (6,3\%o-ről 4,2\%o-re), mind a szülés után a Neonatalis Intenzív Centrumba történő felvételek aránya (14,8\%-ról 13,5\%-ra).

Következtetések: A bemutatott tényezók együttes hatásaként - elsődlegesen a megfelelő és következetesen betartott protokolloknak köszönhetően - a szülésindukciók aránya és sikeressége jelentősen növekedett, a császármetszések aránya szignifikánsan csökkent, javuló perinatalis morbiditási és mortalitási mutatók mellett.

Orv Hetil. 2021; 162(21): 811-823.

Kulcsszavak: császármetszési arány, szülésindukció, császármetszés utáni hüvelyi szülés, perinatalis mortalitás, koronavírus-járvány

\section{How the cesarean delivery rate decreased at the Department of Obstetrics and Gynecology, University of Debrecen during the COVID-19 pandemic}

Introduction: The pandemic caused by the new coronavirus (SARS-CoV-2) has catalized several changes in many fields of our lives, and also at the Department of Obstetrics and Gynecology of the University of Debrecen, Hungary.

Objectives: We wanted to analyse the compound effect of our new local protocols regarding elective labour inductions at term, the coronavirus pandemic and the resulting infection control measures, the merging of the Obstetrics and Gynecology Ward of the Kenézy County Hospital of Debrecen and the University Department of Obstetrics and Gynecology, and also the change of the legal environment.

Methods: Local protocols were introduced: 1. Labour induction. 2. Cervical ripening in labour induction. 3. Choosing the route of delivery after cesarean. 4. Management of pregnancy around term in the case of planned trial of labour after cesarean. We compared the obstetrical data (number of deliveries, cesarean section rate, perinatal outcome and the rate and success rate of labour inductions) before and after the implementation of the protocols. The results were also compared to the Hungarian national database. 
Results: The annual cesarean rate at our department dropped to $33.5 \%$ in 2020 . In the first 9-month period, after the introduction of the new reforms, the cesarean rate decreased to $30.7 \%$, whereas the Hungarian national rate was $40.3 \%$ in 2020 . At our department, $20 \%$ of all the deliveries were induced and $74 \%$ of them led to vaginal deliveries in 2020 , while in 2019 only $11 \%$ of deliveries were labour inductions, and $47 \%$ of these cases were vaginal deliveries. The monthly number of deliveries was rising constantly between January 2020 (250 deliveries) and January 2021 ( 450 deliveries), and the monthly cesarean rate decreased from $41 \%$ to $25 \%$. Comparing the data of 2019 and 2020 , the annual perinatal mortality rate dropped from $6.3 \%$ in 2019 to $4.2 \%$ in 2020 . Neonatal morbidity, as measured by admissions to the neonatal intensive care unit, also decreased (14.8\% in 2019 and $13.5 \%$ in 2020 ).

Conclusions: As a compound result of the described factors, but mainly due to the new protocols, both the rate and the success rate of labour inductions increased significantly, while the cesarean rate decreased with improving perinatal mortality and morbidity.

Keywords: cesarean section rate, labour induction, vaginal birth after cesarean (VBAC), perinatal morbidity, coronavirus pandemic

Deli T, Lampé R, Juhász AG, Kovács T, Daragó P, Bacskó Gy, Török O. [How the cesarean delivery rate decreased at the Department of Obstetrics and Gynecology, University of Debrecen during the COVID-19 pandemic]. Orv Hetil. 2021; 162(21): 811-823.

(Beérkezett: 2021. március 9.; elfogadva: 2021. április 7.)

\section{Rövidítések}

ACOG $=($ American College of Obstetricians and Gynecologists) Amerikai Szülészek és Nőgyógyászok Kollégiuma; COVID-19 = (coronavirus disease 2019) koronavírus-betegség 2019; KEK = Kenézy Gyula Egyetemi Kórház; NST = nonstresszteszt; $\mathrm{PCR}=($ polymerase chain reaction $)$ polimerázláncreakció; $\mathrm{PRCD}=$ (planned repeat cesarean delivery) tervezett ismételt császármetszés; SARS-CoV-2 = (severe acute respiratory syndrome coronavirus 2) súlyos akut légzőszervi szindrómát okozó koronavírus-2; SMFM = (The Society for Maternal-Fetal Medicine) Anyai-Magzati Medicina Társaság; TOLAC $=($ trial of labour after cesarean $)$ hüvelyi szülés kísérlete előzetes császármetszés után; VBAC $=($ vaginal birth after cesarean) császármetszés utáni hüvelyi szülés

$\mathrm{Az}$ új koronavírus (SARS-CoV-2) okozta pandémia nemcsak a hétköznapjainkat alakította át. Számos, már időszerû változás bekövetkeztét katalizálta életünkben, így az egyes orvosi szakterületeken is. Ezt tapasztaltuk meg a debreceni Szülészeti és Nőgyógyászati Klinikán is, amikor az alább bemutatott, új belsố eljárási rendeket vezettük be szülészeti ellátásunkban. Ezeket részben már korábban is terveztük, de bevezetésüket a járvány jelentősen felgyorsította.

Klinikánk igen korán, a járványügyi veszélyhelyzet 2020. március közepi kihirdetésével egyidejúleg ténylegesen szembesült a vírus jelenlétével. Így már azon a héten számos gyors átszervezést hajtottunk végre, ami a járvány terjedésének megelőzését szolgálta. Az országos teljes látogatási tilalom mellett a következők kerültek bevezetésre: spontán szülés és császármetszés után is 48 órás anyai és újszülött-hazabocsátás; a szülőszobai és terhespatológiai osztályos felvétel szigorú szakmai kontrollja és a bent fekvố várandósok számának csökkentése; teljes COVID-részleg kialakítása (mútő, szülőszoba, osztály, ambulanciák); távkonzultáció bevezetése több szakrendelésen, így a COVID-terhesambulancián is; a klinikára történó átvételeket részletes telefonos, checklista alapján történő, írásban rögzített előzetes konzultációhoz kötöttük; a várandósgondozás bizonyos vizsgálatait átütemeztük, távkonzultációba szerveztük, egy részüket pedig felfüggesztettük; a járvány második hullámában, novembertől a 38. terhességi héten minden várandósnál koronavírus-PCR-szúrést vezettünk be.

Közleményünk témája szempontjából kiemelkedő jelentôségü döntés született már az elsó 24 órában. A Terhesambulancia forgalmának további csökkentése érdekében terminusközelben, de legkorábban a 39. hét betöltése után, szövődménymentes terhességben - egyéb szülészeti indikáció hiányában - a megfelelő feltételek fennállása esetén felajánlottuk a várandósoknak az elektív szülésindukció lehetőségét. Terminustúllépés esetén a magzati állapot ellenőrzésére korábbi gyakorlatunkban naponta hívtuk vissza a várandósokat (túlnyomórészt NST-vizsgálatra), és jelenleg is ezt a gyakorlatot követjük mindazon esetekben, amikor a várandósok a szülésindukció lehetőségéről történő részletes tájékoztatást követôen a szülés spontán megindulására való várakozás mellett döntenek.

A terminusközelben orvosi indok nélkül végzett elektív szülésindukciók kérdését az elmúlt évek nagy multicentrikus vizsgálatai ismét fókuszba állították, és az eredmények a szülészetben világszerte komoly vitákat generáltak. Ezek a vizsgálatok elsősorban az amerikai ARRIVE [1] vizsgálat, továbbá Middleton és mtsai Cochrane-metaanalízise 2018-ból [2], valamint a holland INDEX [3] és a svéd SWEPIS [4] tanulmányok 2019-ből. A témával foglalkozó szakirodalom részletes bemutatása nem célja e közleménynek, de Dekker és Bertone 2020 februárjában a fenti és egyéb, a témával kapcsolatos további klinikai vizsgálatok áttekintésével részletes és jól strukturált összefoglalót írt [5]. A 2018 
augusztusában publikált ARRIVE-vizsgálat eredményei azt igazolták, hogy a 39. és a 40. héten elektíven végzett szülésindukció - a várakozással összehasonlítva ( „expectant management”) - nem volt ugyan hatással a neonatalis halálozásra, viszont szignifikánsan csökkentette az újszülöttek légzéstámogatásának szükségességét (3,0\% vs.
4,2\%), a császármetszés gyakoriságát (19\% vs. 22\%) és a terminus körüli hipertenzív állapotok kialakulását (9\% vs. 14\%). Mindezekre tekintettel az ACOG és az SMFM 2018-ban olyan gyakorlati protokollt adott ki, mely alapján a 39. hét után mérlegelhető az elektív szülésindukció, ha a következő feltételek teljesülnek: (1) ez a gravida

1. táblázat | A szülészeti ellátásunkban 2020. áprilistól bevezetett szakmai változtatások és az ezek feltételeit megteremtő gyakorlati intézkedések

Szakmai változás
(1) A szülésindukciós módszer Bishop-score-ér
téktőll függó megválasztása.

(2) Elözményi l császármetszést követően a VBAC-score (Grobman-féle) kötelezö kalkulációja a szülés módjáról történő konzultáció során.

(3) A szülés latens és aktín fázisának megkülönböztetése (határ: $4 \mathrm{~cm}$ cervixtágasság), a két fázis különböző szemléletű menedzselése.

(4) A sikertelen szülésindukció (,failed induction”) pontos definiálása álló és nem álló burok mellett, illetve kontrakciók esetén és azok hiányában. rek standardizálása (oxitocin, prosztaglandinkészítmények, ballonkatéter, laminaria, burokrepesztés, obszerváció stb.) 'evidence-based' módon.

(6) Sikertelen szülésindukció esetén követendo" eljárásrend megalkotása, mely a császármetszés lehetősége mellett a más módszerû indukció, illetve a gravida preferenciájától függően az ún. halasztott indukció („postponed induction”) lehetőségét is tartalmazza.

(7) A cervixérlelés (általában prosztaglandinnal) megfeleló idejének biztosítása: maximum 2 alkalommal adunk prosztaglandint, de a második alkalmazása előtt 24 órát várunk. Ezen idő alatt a sikertelen szülésindukció diagnózisa sem mondható ki.

(8) A szülésindukciók és császármetszések kapcsán személyre szabott tervezés és részletes tájékoztatás, illetve a várandósok döntésbe történő bevonása.
(5) A szülésindukció során alkalmazott módsze-

Gyakorlati megvalósítás

Szülésindukciós adatlap bevezetése, mely minden szülésindukció indikálásakor kitöltésre kerül.

Ezen egyebek mellett jelölni kell a cervix érettségét jelző, a módosított Bishop-score elemei alapján számított értéket, továbbá a 12. heti ultrahangvizsgálat alapján kalkulált terminust.

- VBAC-kalkulátorok bevezetése, melyek minden orvos mobiltelefonján elérhetók.

- A leleteken a VBAC-score kötelezö feltüntetése.

Az egyes beavatkozások, gyógyszeres kezelések vonatkozásában a szülés két fázisában változó idöintervallumok megadása a protokollban.

Oktatás, ellenőrzés, a „sikertelen szülésindukció” diagnózis megfelelő használatának követése.

(1)

Részletes protokoll (a módszerek alkalmazásának feltételei, pontos adagolási, alkalmazási mód stb.) és ezek betartásának számonkérése.

Az orvosok oktatása mellett a szülésindukció elkezdése elótt a várandósok részletes, elózetes tájékoztatása az ilyen esetekben lehetséges forgatókönyvekról.

- A türelmes cervixérlelés feltételeként ún. elöszülo"szobát („pre-szülo"szobát”) alakitottunk ki. Itt megadott protokoll szerint történik az általános terhesosztálynál szorosabb szülésznői/orvosi észlelés (CTG-vel, de szükség esetén az ultrahangvizsgálat is helyben elérhető). Ugyanakkor a szülőszobánál nyugodtabb körülmények biztosítják a legtöbbször másnap zajló szülés elött a várandós pihenését.

- Ehhez szükséges a gravidák elözetes részletes tájékoztatása (lásd következő pont), ennek részeként a „méhszájérlelés” és a „tényleges vajúdás és szülés” fogalmainak szétválasztása, ami növeli a várandósok türelmét, és elégedettségüknek feltétele.

- Erre napi rendszerességü, ún. perinatológiai konzultációkat hoztunk létre. Ezek során a Perinatológiai Részleg két vezetője a szakmailag kérdéses és a 'rutin' esetekben is személyesen konzultál az elektív indukció előtt álló minden várandóssal, illetve gyakran háromoldalú konzílium történik (várandós-kezelőorvos-részlegvezető). Ezekről a konzultációkról mindig születik részletes elektronikus és nyomtatott lelet.

- Standardizáltuk azokat a témákat, adatokat is, melyekröl a szülésindukcióval vagy VBAC-kkel kapcsolatban a gravidát mindenképpen tájékoztatni kell a várandósgondozás során és a terhesség befejezése előtt. Az adott esetben releváns adatokról a várandós tájékoztatása előzetesen lehetőleg a kezelőorvosa által is minden esetben megtörténik.

(9) A szülöszobai kapacitás és személyzet illesztése a tervezhető elektív indukciókhoz/császármetszésekhez.

(10) Az új rendszer múködésével kapcsolatos eredmények monitorizálása és a visszajelzések alapján történö korrekciója.

(11) Az orvoskollégák együttmüködésének elnyerése, a személyi szülészeti ellátás miatti érdekellentétek csökkentése.
- Az elektív szülésindukciók napi limittel történó elójegyzése kötelező az informatikai rendszerben és a mütéti programban.

- Nagyszámú tervezett elektív indukció, császármetszés esetén eloozetes egyeztetés után a szülőszoba szülésznői és orvosi létszámának tervezett megerôsitése.

- Személyes vezetöi ellenörzés mind a nappali, mind az ügyeleti időszakra vonatkozóan.

- Szülésindukciós napló rendszeresitése (a szülési és mútéti naplókhoz hasonlóan).

Az orvosok munka-és ügyeleti idejének figyelembevétele az indukciók időzítése során úgy, hogy a szakmai protokoll betartása minden esetben teljes mértékben megvalósuljon.

- A körülmények hozták el a személyi szülészeti ellátás átmeneti felfüggesztését, mely ezt a konfliktust automatikusan megszüntette.

CTG = kardiotokográfia; VBAC = császármetszés utáni hüvelyi szülés 
preferenciája is, (2) az intézmény biztosítani tudja az esetleges hosszabb szülésindukciók infrastrukturális hátterét, és (3) a sikertelen szülésindukció („failed induction”) szigorúan definiált, és ezt a definíciót protokollszerüen alkalmazzák $[6,7]$.

\section{Módszerek}

A hazai [8-10] és a nemzetközi [11-24] ajánlások, valamint a vonatkozó szakirodalom áttekintése után - a helyi körülmények figyelembevételével - részletes protokollt dolgoztunk ki a szülésindukciók végzésére és ezen belül is külön algoritmust a nulliparák cervixérleléssel kezdett indukciójára. Ezektől független további két protokollt készítettünk az előzményi l császármetszés utáni terhességek terminus körüli ellátására: első lépésben annak eldöntésére, hogy császármetszés utáni hüvelyi szüléssel (VBAC, vaginal birth after cesarean) való próbálkozást (TOLAC, trial of labour after cesarean) vagy inkább tervezett ismételt császármetszést (PRCD, planned repeat cesarean delivery) javasoljunk-e a várandósnak. Azoknak az eseteknek az ellátására, amikor a gravidával közösen TOLAC mellett döntünk, külön protokollban foglaltuk össze a VBAC-t leginkább elősegítő, a 39-41. hét közötti várandósgondozásra vonatkozó eljárásrendet.

A protokollokat a cikk végén található 1 . és 2 . függelékben mutatjuk be (terjedelmi okok miatt a négyből kettőt).

A helyi protokollok elkészítése önmagában sem egyszerü feladat, s különösen nem az egy hektikus járványhelyzetben. Ehhez áttekintettük a témában 2020. márciusig publikált, evidencián alapuló szülészeti szakirodalmat. Ez azonban még kevés ahhoz, hogy sok évtizedes, a napi rutinban meggyökeresedett szokásokat megváltoztassunk. Ezért a kész protokollok bevezetése a napi gyakorlatba ezt követôen még sok hónapnyi kitartó munkával járt - sőt jár azóta is. Ez magában foglalja az orvosok és szülésznők egyenkénti, személyes oktatását, a protokollok közös értelmezését és - gyakran - kikérdezését is; a protokollok és eljárásrendek betartásának folyamatos ellenőrzését (az egyes esetek szintjén, a kollégákkal személyesen átbeszélve a protokolltól való esetleges eltérés indokait, felvállalva akár a konfliktusokat is); a szülészeti eredmények folyamatos követését és a 'feedback' jellegü korrekciókat; illetve az új rendszerhez szükséges szervezési és infrastrukturális háttér megteremtését. Az 1. táblázatban felsoroljuk, milyen szakmai és szemléletbeli változtatásokra került sor a szülészeti ellátásban, illetve hogy ezen változtatások bevezetése milyen szervezési átalakításokat igényelt.

\section{A protokollokon túli egyéb események hatása szülészeti ellátásunkra}

A járványhelyzet eszkalálódásával párhuzamosan, röviddel a protokollok bevezetése után, két további, hatalmas horderejü változás következett be klinikánk életében.
A megyei kórházként funkcionáló Kenézy Gyula Egyetemi Kórház (KEK) Szülészeti és Nőgyógyászati Osztályát, Debrecen másik nagy szülészeti ellátóját, 2020. november 5-én este, szó szerint egyik óráról a másikra, azonnali hatállyal COVID-ellátó osztállyá nevezték ki, a mentőket pedig haladéktalanul klinikánk szülőszobájára irányították át. Így jött létre 24 óra leforgása alatt az ország egyik legnagyobb forgalmú szülészete: az évi közel 3100 szülést ellátó klinika kibővült a KEK évi 2200 körüli szülésével, az azonnal átvezényelt orvosokkal és szakdolgozókkal. Ugyanakkor erre a felduzzadt betegforgalomra mindössze a klinika korábbi kubatúrája állt rendelkezésre. $\mathrm{Az}$ 1. ábrán jól látható a novemberben azonnal megugró és azóta is folyamatosan emelkedő szülésszám.

Újabb két hónappal később került sor a médiában nagy figyelmet kapott „hálapénzbotrányra”. A 2021. január l-től bevezetett rendelkezések értelmében hazánkban e naptól bứncselekménynek számít a hálapénz felajánlása és elfogadása. Mivel a munkaidőn túli szülészeti készenlétért és munkavégzésért ( „személyi szülészeti ellátás”) utólagosan adott juttatás nem került megkülönböztetésre a hálapénz egyéb formáitól, a debreceni Szülészeti Klinika orvosai önkéntes, de egyhangú döntéssel megszüntették a munkaidőn túli felkért, személyhez kötődő szülésvezetést. A szüléseket azóta is a megerősített ügyeleti team látja el. Ennek a döntésünknek nagy lett a sajtóvisszhangja, de a várandósok hamar alkalmazkodtak a kialakult helyzethez, és januárban a szülések száma és a hüvelyi szülések aránya nemhogy csökkent volna, hanem tovább emelkedett klinikánkon.

\section{Eredmények}

A fent felsorolt események összességükben vezettek azokhoz a változásokhoz, amelyek eredményeit az 1-6. ábrán is bemutatjuk. Klinikánkon 2020 januárja és 2021 januárja között a havi szülésszám kb. 250-ről 450-re nőtt, a havi császármetszésráta pedig közel 41\%-ról 25\% alá csökkent (1.ábra). Bár a fluktuáció miatt ezeknek az adatoknak általában az egyhavinál hosszabb periódusra vonatkozó bemutatása a megszokott, ebben az időszakban olyan sok változás történt néhány hónap alatt, hogy érdemes a havi számokat is megnézni. Indokolja ezt az a tény is, hogy januárban a klinikán a havi szülésszám elérte egy kisebb városi kórház éves szülésszámát. Az egyes intézkedések, események időbelisége is látható az 1 . ábrán.

A 2020. évi császármetszési arány 33,5\% lett, így a világszerte folyamatosan emelkedő császármetszés-gyakoriság mellett olyan szintre esett vissza, amilyet legutóbb Magyarországon és Debrecenben is egy évtizeddel ezelőtt láthattunk (2. ábra). Ha a változtatások elindításától, 2020. áprilistól 2021. január végéig eső időszak 3148 szülését nézzük, ez az arány még kedvezóbb: 30,7\% (967 sectio/3148 szülés). A Tauffer-féle szülészeti statisztika 2020. évi adatai alapján [25] Magyarország 


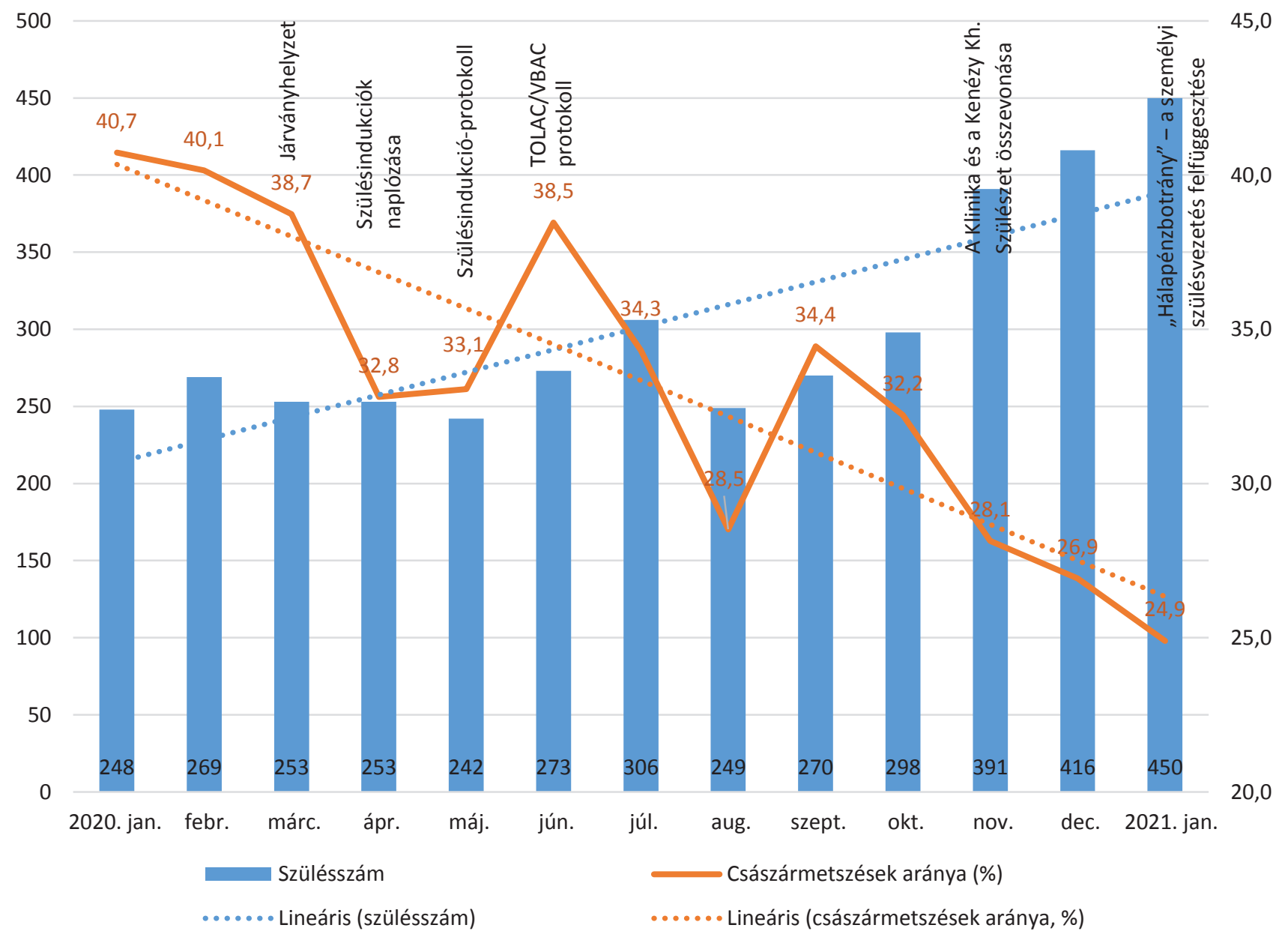

1. ábra $\quad$ A havi szülésszám és a császármetszések arányának alakulása a debreceni Szülészeti Klinikán 2020. január és 2021. január között. Az ábrán feltüntettük a szülészeti ellátásra hatással lévő események időpontját is

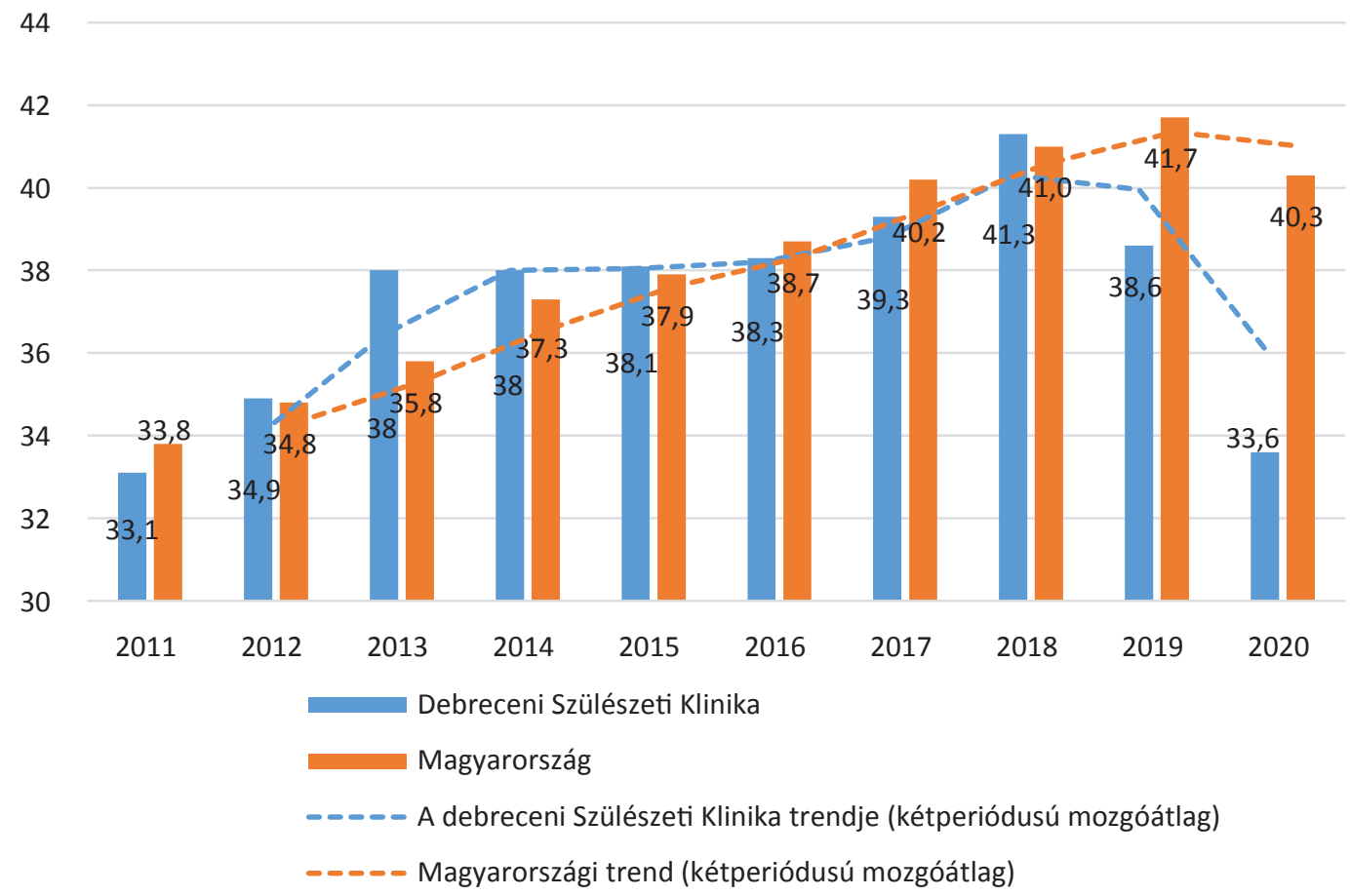

2. ábra | A császármetszések arányának alakulása Magyarországon és a debreceni Szülészeti Klinikán az elmúlt évtizedben (\%) 


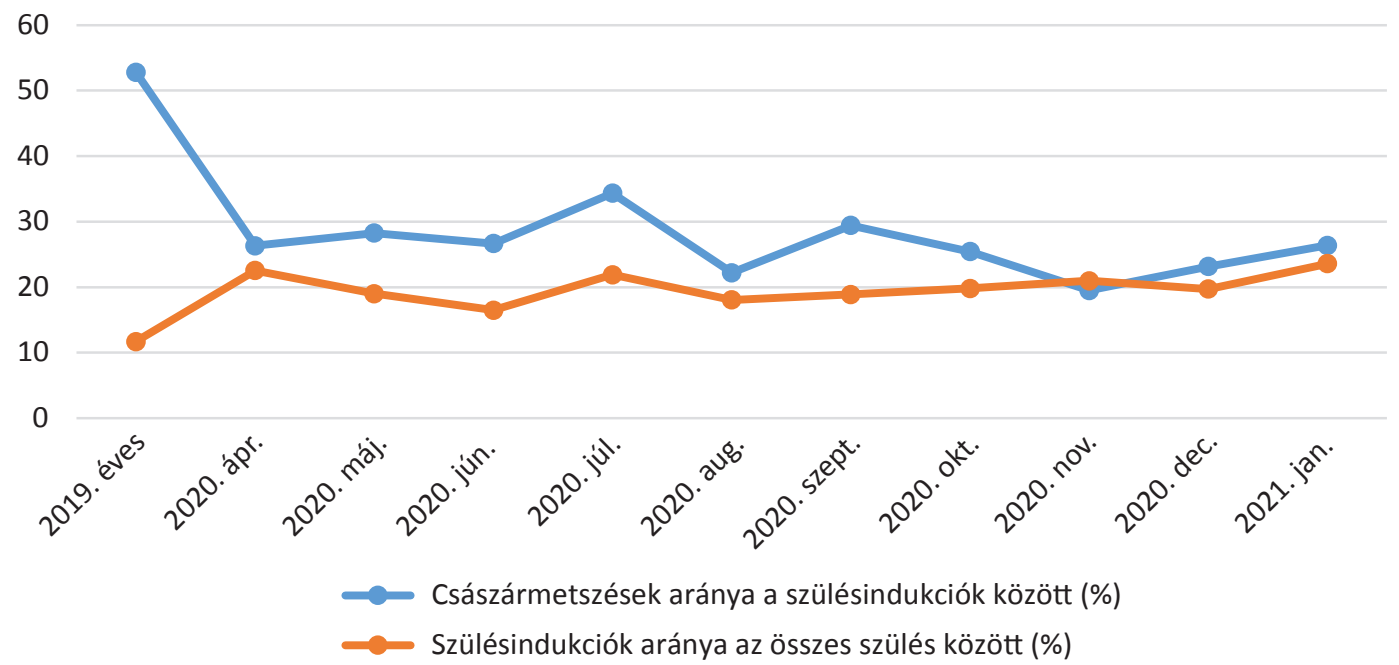

3. ábra $\quad$ A szülésindukciók összes szüléshez viszonyított arányának és sikerességének mutatói a változtatások előtti évben (2019) és a változtatások kezdetétôl (2020. április 1.)
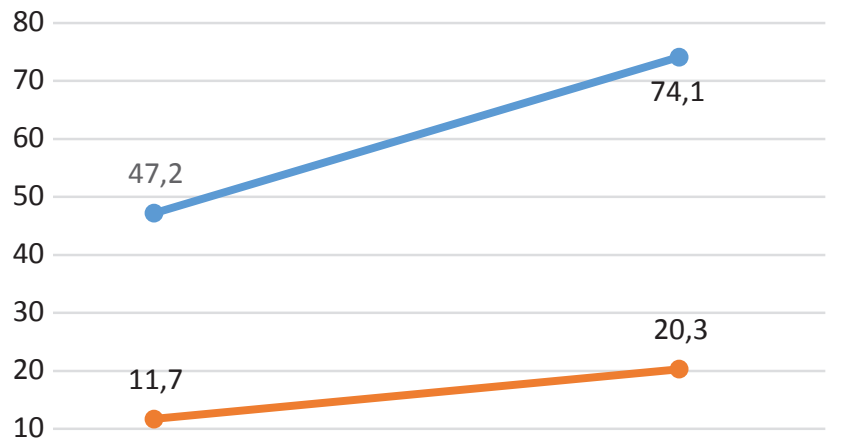

0

2019. jan.-dec.

2020. ápr.-2021. jan.

—Hüvelyi szülések aránya a szülésindukciók között (\%)

—Szülésindukciók aránya az összes szülés között (\%)

4. ábra

A szülésindukciók összes szüléshez viszonyított arányának és sikerességének változása az új belső eljárásrendek bevezetése előtti naptári évben (2019) és azok bevezetése óta (2020. április-2021. január)

megyéi és Budapest viszonylatában Hajdú-Biharban az egyik legalacsonyabb a császármetszések aránya, annak ellenére, hogy itt múködik a legmagasabb progresszivitási szintü négy egyetemi szülészeti klinika egyike, azaz itt látjuk el a legkomplikáltabb, potenciálisan legtöbb császármetszéshez vezető eseteket.

A változások részeként - a 2019. évi 11,7\%-kal összevetve - 2020. április és 2021. január között az összes szülés 20,3\%-ában történt szülésindukció, és míg 2019ben a szülésindukcióknak csak 47,2\%-a végződött hüvelyi szüléssel, ez az arány 2020-ban 74,1\%-nak adódott (3. és 4. ábra).

A császármetszések arányának csökkentése azonban semmiképp sem lehet mindenekelőtt megvalósítandó cél. Ezek az eredmények mit sem érnének, ha az anyai és/vagy neonatalis morbiditás és mortalitás emelkedése kísérné. Az 5. ábrán bemutatott adatok egyértelmúen jelzik, hogy a közleményben részletezett szülészeti ellátásbeli változásokkal párhuzamosan a 2019. évi 6,6\%o-es perinatalis mortalitás 2020 -ban $4,2 \%$-re esett vissza, a 6 . ábrán pedig azt láthatjuk, hogy az újszülöttek intenzív ellátást igénylő állapotainak gyakorisága folyamatos csökkenés után szintén ötéves mélypontra esett. Egyidejúleg az anyai szövődmények gyakoribbá válását sem észleltük. Mindezek igazolják az ARRIVE-vizsgálat eredményei alapján előzetesen várt javuló kimenetelt, amelyet a helyi protokollok szigorú betartásával végzett szülésindukciók mellett hazai viszonyok között sikerült elérnünk.

\section{Megbeszélés}

A bemutatott szülészeti eredmények létrejöttében több tényező játszott közre, és ezek változó arányú szerepe feltételezhető.

- A koronavírus-járvány katalizálta a részben már korábban is tervezett helyi protokollok, új belső eljárási rendek elkészítését és gyakorlati bevezetését.

- Ugyancsak a járvány indított minket arra, hogy - a korábbi szokásokkal szakítva - az ARRIVE-vizsgálat eredményeire és az ezekre hivatkozó szakmai ajánlásokra támaszkodva már a 4l. gestatiós hét előtt, de legkorábban a 39. hét betöltése után, külön orvosi ok nélkül is elektív szülésindukciót ajánljunk fel a várandósoknak. Az ilyen szemlélet mellett végzett 750 . szülésindukción túl kijelenthetjük, hogy a rendszer jól múködik. (Az adatok részletes feldolgozása jelenleg is folyamatban van.)

- A szülésindukciók láthatóvá tétele (naplózás, előjegyzés, részlegvezetői konzultáció stb.) és engedélyezése a korábban a „szürke zónában”, valós orvosi indikáció nélkül programozott, de indukcióként soha nem regisztrált szüléseket is bevonta a statisztikába, és az ellátásban részt vevőket a protokoll betartására késztette. 
45

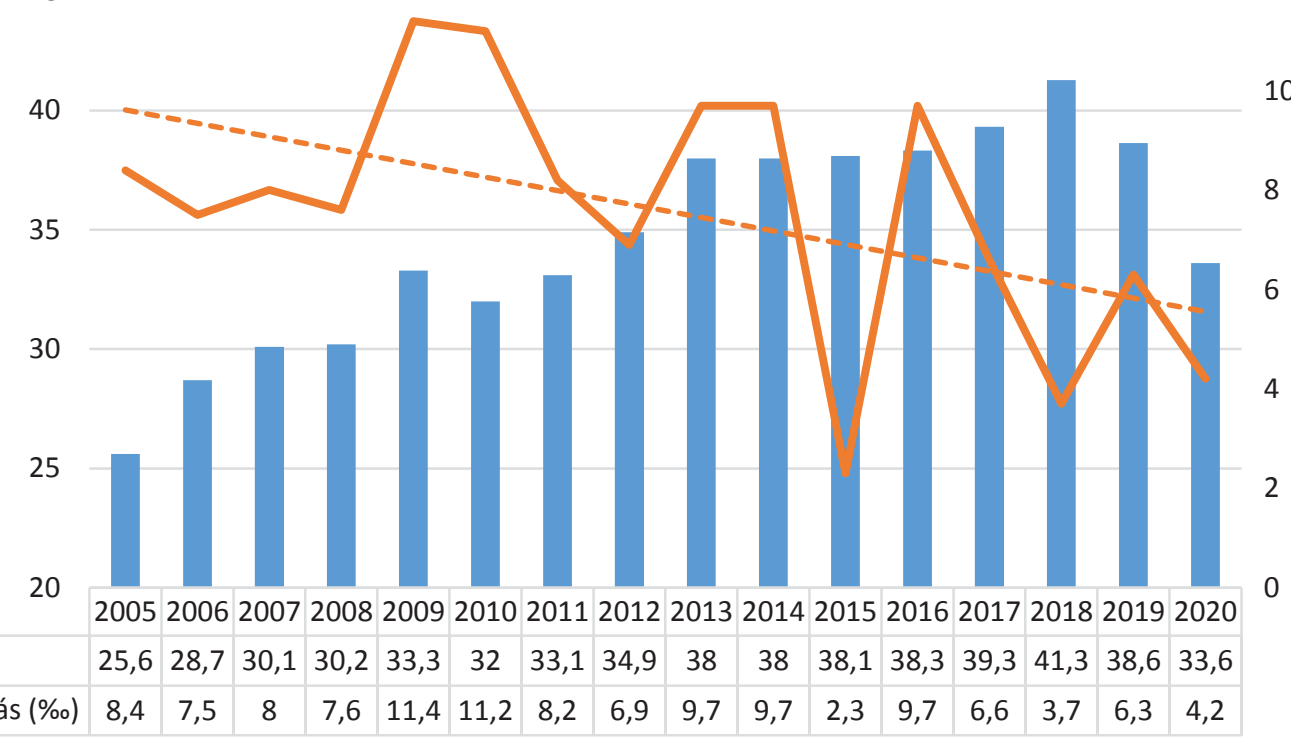

Lineáris trend (éves perinatalis mortalitás, \%o)

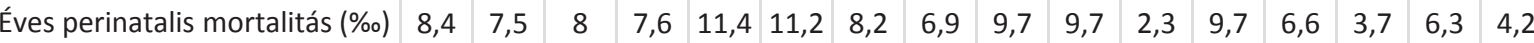

Éves sectioráta (\%)

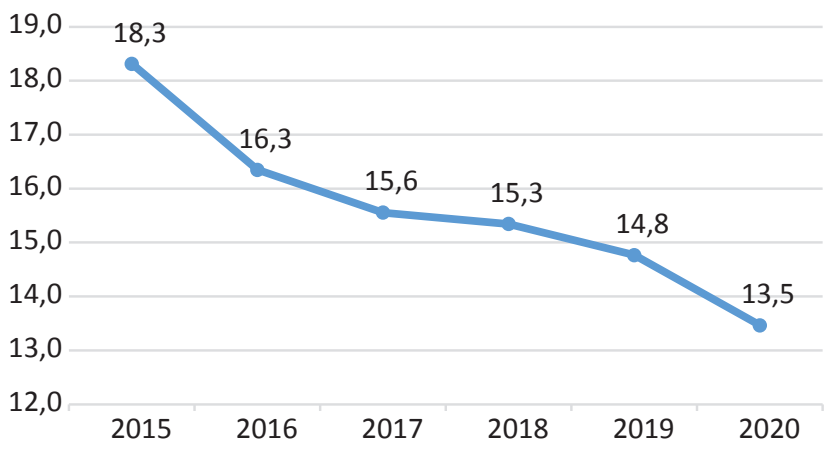

6. ábra $\quad$ A Neonatalis Intenzív Centrumba történt utalások aránya az összes élve született újszülöttre vonatkoztatva 2015 és 2020 között a debreceni Szülészeti Klinikán (\%)

- A két tapasztalt részlegvezetővel folytatott részletes, személyes és személyre szabott konzultációk számos várandóst győztek meg a hüvelyi szülés előnyeiről. A VBAC napi gyakoriságú a szülőszobánkon, ritkán napi 3 is van, és az elmúlt időszakban előzményi 2 császármetszés utáni hüvelyi szülésünk is volt több esetben. Az utóbbira nem biztatjuk ugyan a várandósokat, ső́t az ajánlásoknak megfelelően az ismételt császármetszést javasoljuk, de ha a gravida a részletes írásbeli felvilágosítás és a kockázatok ismertetése után is ragaszkodik a TOLAC-hoz, annak legkisebb kockázattal járó feltételeit biztosítjuk. Bár ennek az esetszámnak evidenciaértéke nincs, érdemes megjegyezni, hogy a tavalyi 3 tervezett, előzményi 2 sectio utáni VBAC mindenféle szövődmény nélkül zajlott le.

- A klinika beteganyagában a magas kockázatú terhességek, koraszülések aránya lényegesen csökkent az alacsonyabb progresszivitási szintû, de nagy betegforgalmú KEK-kel való összevonást követően. Ez értelemszerüen a császármetszések arányát is befolyásolta, ám az összevonás önmagában nem magyarázza az észlelt jelentős csökkenést. Ezt a következő adatok igazolják:

- Már az összevonás előtt, a változtatások áprilisi bevezetésétól októberig jelentősen csökkent a császármetszések aránya az akkor még önálló egyetemi klinikán: $633 / 1891=33,4 \%$ (a 2020. év első 3 hónapjában $307 / 770=39,9 \%$; 2019-ben 1180/3064 $=38,5 \%)$.

- A megelőző 2 év klinikai és KEK-adatai alapján kiszámoltuk, hogy önmagában az összevonás milyen császármetszési arányt eredményezett volna. A két intézményben 2019. január-december, illetve 2020. január-október között összesen 5245 és 4539 szülés volt, ezek közül a szülések 58,4\%-a és 58,6\%-a zajlott a klinikán. Az összevonást követő első 5 hónapban (2020. november-2021. március) az összevont intézményben 2087 szülés zajlott, ebből 586 császármetszést végeztünk, ami a szülések 28,1\%-a. A két intézmény 2019. évi császármetszési arányaival (38,5\% és $26,9 \%)$, illetve az egyes intézményekben zajlott szülések arányával (58,4\% és $41,6 \%)$ történt súlyozott kalkuláció alapján ugyanebben az időszakban $33,7 \%$ császármetszési arányt kaptunk volna, ha a 2019. évhez képest az összevonáson kívül semmi más változás nem történik. Ezzel hasonlítandó össze a valóságban tapasztalt $28,1 \%$. Véleményünk szerint a várható és a tapasztalt értékek közötti 5,6 százalékpontnyi különbség az, ami az összevonáson túl egyéb tényezőknek, nevezetesen a szülészeti ellátásban bevezetett változtatásoknak tulajdonítható ebben az időszakban. Ez egyébként hasonló nagyságrendű változás, mint amilyet a változ- 
tatások kezdetétől az összevonásig, pusztán a klinika szülészeti eredményeiben észleltünk. A 2020. április-október közötti időszak 33,4\%-os császármetszésaránya a 2020. első negyedévi 39,9\%-nál és a 2019. évi 38,5\%-nál 6,5\%-kal, illetve 5,1\%-kal alacsonyabb.

- Eredményeink a koronavírus-járvány idején születtek, így felmerülhet a gondolat, hogy a koronavírus-fertőzés megváltoztathatta a koraszülés gyakoriságát, maga után vonva a császármetszések arányának csökkenését. Az elmúlt év során számos közlemény látott napvilágot a témában, de ezek ellentmondásos következtetésekre jutottak. Egyes munkacsoportok (például Spanyolországban [26], az Egyesült Államokban [27]) nem találtak változást a koraszülések arányában a pandémia alatt, míg mások (például Írországban [28], Dániában [29]) az extrém kis súlyú koraszülések számának jelentős csökkenéséről számoltak be. Az utóbbi hátterében a lezárások miatti megváltozott szokásokat, a csökkent fertőzési kockázatot (például hüvelyi infekciók) és a kisebb mértékú anyai fizikai aktivitást is felvetették. Saját szülészeti statisztikáinkat átnézve, a debreceni Szülészeti Klinikán nem volt érdemi változás a koraszülések gyakoriságában 2019 és 2020 között: klinikánkon 2020-ban a koraszülöttek aránya az összes újszülött közül 13,6\% (486/3575) volt, 2019ben pedig 13,0\% (414/3181). Mivel mind az anyai COVID-19-betegség, mind a koraszülöttség arányának enyhe emelkedése a császármetszések arányát inkább növelő tényező, biztosan kimondható, hogy az elért alacsonyabb császármetszésarány nem a koronavírus-fertőzés koraszülésekre kifejtett kedvező hatásának következménye.

- A személyi szülészeti ellátás kollektív felfüggesztésének hatásáról korai még nyilatkozni. Mindenesetre, ha az orvos egyéni érdekei, egyéb elfoglaltságai, munkaidejének lejárta stb. kikerülnek az „egyenletből”, egygyel kevesebb olyan hatás marad, amely a tisztán szakmai döntéshozatalt akadályozza.

Magyarországon 2020. március 11-én hirdették ki a járványügyi veszélyhelyzetet, és március 15-én jelentették a járvány első halálos áldozatát. Az ezt a vasárnapot megelőző péntek 13-án vettük le az első, később pozitívnak bizonyuló koronavírustesztet a debreceni klinika szülőszobáján, egy előtte néhány órával császármetszésen átesett, pancytopeniás betegünknél, aki a mütét után nem sokkal belázasodott és dyspnoéssé vált. Jelenleg - 2021. március végén - a járvány 13. hónapjában, a harmadik fertőzési hullám felszálló szárán (csúcsán?), amikor a COVID-19 halálos áldozatainak száma hazánkban még mindig naponta 200-300 fó, és számos „COVID-os” szülésen, mútéten, betegvizsgálaton vagyunk túl, kicsit furcsa visszagondolni azoknak a korai „járványnapok"-nak az eseményeire. A cikk elején felsorolt számos intézkedés és változtatás akkor nem szokványosnak, sőt néha eretneknek tünhetett, időnként a betegekkel és az orvoskollégákkal is konfliktusokat oko- zott. Ezen intézkedések jó részéról azóta kiderült, hogy nem csupán a járványhelyzet szempontjából voltak kedvezők. Az azóta eltelt idő számos előnyüket igazolta, a változások az elmúlt egy év alatt pedig megszokottá váltak klinikánkon. Sok közülük feltehetően tartósan is meg fog maradni. Az egyik legmesszebb mutató változás a szülésindukciók és a TOLAC/VBAC szülések eljárásrendjének átstrukturálása volt, aminek az előzőekben bemutatott eredményei messze felülmúlták korábbi várakozásainkat.

Befejezésként azonban két dolog feltétlenül hangsúlyozandó. Egyrészt fontos ismét kiemelni, hogy a császármetszésráta nem önmagáért csökkentendő, l’art pour l'art jelleggel. Az Egészségügyi Világszervezet 1985-ben megfogalmazott ajánlása szerinti 10-15\%-os sectioráta, mely felett további javulás a magzati és anyai morbiditási mutatókban már nem várható, napjainkban idejétmúltnak tekinthető, és az is kérdéses, hogy valaha evidenciákon alapult-e. Ugyanakkor a Journal of the American Medical Association (JAMA)-ben 2015-ben publikáltak egy Harvard-Stanford-kollaborációban készült tanulmányt, amelynek adatai szerint kb. 20\%-os országos sectioráta felett az anyai és magzati morbiditás és mortalitás további javulása az egyre több császármetszéstől már nem várható [30]. Lényegében hasonló eredményre jutottak Ye és mtsai [31], illetve Volpe is [32].

A másik kiemelendő szempont az anya kívánságának figyelembevétele. Ahogy Papp Zoltán professzor is rávilágít egy korábbi rövid írásában [33], nem lehet figyelmen kívül hagyni a szülészekre nehezedő társadalmi nyomást az anyai kérésre történő császármetszések tekintetében. Magyarországon jelenleg pusztán anyai kérésre nem végezhetó császármetszés, de ez a jogi helyzet társadalmi igény esetén a jövőben akár meg is változhat. Az igazi kérdés az, hogy ha, illetve amikor a szülés módja szabadon megválasztható lesz, bizonyosan megkapják-e a várandósok a részletes és adekvát információt mind a hüvelyi szülés, mind a császármetszés rövid és hosszú távú anyai és magzati előnyeiról és hátrányairól is. Ebben csak akkor bízhatunk, ha elméletben és gyakorlatban egyaránt megfelelően felkészült, olyan szülészek adják majd ezt a tájékoztatást a várandósoknak, akiknek sem kényelmi, sem anyagi jellegű személyes érdekük nem füződik a császármetszés végzéséhez.

Anyagi támogatás: A közleményben ismertetett munka és a kézirat megírása anyagi támogatásban nem részesült.

Szerzői munkamegosztás: A közleményben hivatkozott protokollok elkészítésében részt vett: D. T., L. R., J. A. G., K. T., D. P., T. O. A klinikai gyakorlatba való bevezetésben, a szükséges gyakorlati változtatásokban részt vett: D. T., T. O., B. Gy., L. R. A közleményt elkészítette: D. T., T. O. A cikk végleges változatát az összes szerző elolvasta és jóváhagyta.

Érdekeltségek: A szerzőknek nincsenek érdekeltségeik. 
1. függelék |A szülésindukció protokollja

DE KK Szülészeti és Nőgyógyászati Klinika, 2020. 04. 22.

1. LÉPÉS A szülésindukció indikációja: ld. Szülésindukciós eljárásrend (adatlap, napló, előjegyzés, bemutatás, elektív vagy orvosi indikációjú indukció stb.). *

\section{LÉPÉS A szülésindukció időzítésének megtervezése* *}

3. LÉPÉS A szülésindukció elkezdése előtt a szülőszobán

1) NST (szükség esetén tokográfia is megindult vagy induló szülés kizárására).

2) A Bishop-score ellenőrzése.

3) A magzat fekvésének ellenőrzése szükség szerint ultrahangvizsgálattal is.

\section{LÉPÉS A szülésindukció módszere}

- Bishop-score $\leq 5$ : cervixérlelés (prosztaglandin vagy mechanikus).

- Bishop-score $\geq 6$ : cervix $\geq 4 \mathrm{~cm}$ : burokrepesztés, oxitocinos infúzió (a koponyának a burokrepesztéshez kedvezőtlen helyzeténél oxitocinos infúzió, burokrepesztés); cervix $\leq 3 \mathrm{~cm}$ : max. $1 \times$ prosztaglandin egyéni mérlegelés után. ***

\section{LÉPÉS Sikertelen szülésindukció $* * * *$}

- Álló burok mellett (burokrepesztés nem kivitelezhető cervix $\leq 1 \mathrm{~cm}$ miatt)

1) A 2. prosztaglandin után 6-24 óra eltelt, zárt cervix $(\leq 1 \mathrm{~cm})$, nincs méhtevékenység.

2) Az 1. vagy 2. prosztaglandin után rendszeres méhtevékenység (CTG-vel regisztrálva!) min. 12 óra, de zárt cervix ( $\leq 1 \mathrm{~cm})$.

- Nem álló burok mellett (ilyenkor a buroksapka megrepedésétől/repesztésétől, a burokrepedés komplettálásától számolunk, a magas burokrepedés a szülés elősegítéséhez sokszor nem elégséges)

3) Burokrepesztés-oxitocinos infúzió után sincs méhtevékenység min. 18 h (de 24 h is lehet) max. dózisú infúzió után, méhszáj: $\leq 4 \mathrm{~cm}$.

4) Burokrepesztés-oxitocinos infúzió után rendszeres, CTG-n regisztrált (!), közepes intenzitású méhtevékenység min. 12 órán át, de a cervix $\leq 4 \mathrm{~cm}$.

Sikertelen szülésindukciót osztályvezetô mondhat ki. Ö megvizsgálja a gravidát, hogy

1) ellenőrizze, ő sem tudja-e megrepeszteni a burkot, ha az még áll,

2) az aktuális Bishop-score-t megítélje a továbbiak eldöntéséhez.

6. LÉPÉS Sikertelen szülésindukció esetén további lehetőségekről döntés*****

1) Másik módszer alkalmazása: ballonkatéter, laminaria, oxitocin (annak hatásideje után, ha továbblépés, burokrepesztés stb. nem lehet, császármetszést javasoljunk).

2) Császármetszés (rendszeres méhtevékenység esetén mielőbb elvégzendő az atonia kockázata miatt, méhtevékenység nélkül néhány órát halasztható).

*Osztályvezető és korlátozott osztályvezetői jogkörrel megbízott (ún. szub.-os) indikálhatja saját betegének.

Nem osztályvezetők esetén: a részlegvezető indikálja a szülésindukciót.

**A szülésindukció időzítése

A 39. héten a burok alsó pólusának leválasztása („membrane sweeping/stripping”) némileg csökkenti a formális szülésindukcióra kerülő esetek számát. A gravida tájékozott beleegyezésével végezhető.

1) Primipara cervixérlelés nélkül vagy multipara cervixérleléssel vagy a nélkül: reggeli indítás a korábbi szokások szerint: 6:00-8:00 órakor burokrepesztés, oxitocinos infúzió vagy prosztaglandin (vagy ballon stb.)

2) Primipara cervixérleléssel:

i) Elsődlegesen reggel 6:00-8:00 órakor kezdődik az indukció.

ii) Ha a cervixstatus alapján 1 prosztaglandin után a burok reggel valószínűsíthetően megrepeszthető lesz, válogatott esetekben egyéni mérlegeléssel a gravidával történő megbeszélést követően 1 prosztaglandin alkalmazása 20:00 órakor is szóba jön.

Részletesen lásd a vonatkozó algoritmust.

*** Szülésindukciós módszerek

\section{Prosztaglandin}

- Prostin tabletta (dinoproszton-prosztaglandin E2, $3 \mathrm{mg}$ ): 24 óra alatt max. 2×, min. 6 óra elteltével; ellenjavallt: TOLAC esetén.

- Prepidil gél (dinoproszton-prosztaglandin E2, 0,5 mg): 24 óra alatt max. 3× adható, mi összesen $2 \times$ javasoljuk, legkorábban 6 óránként; alkalmazása Bishop-score $\leq 5$-nél mindenképp mérlegelendő.

Prosztaglandinfelhelyezés TILOS: legalább 5 perces méhtevékenység esetén.

Ballon

- 40-80 ml fiziológiás sóval feltöltve a belső méhszáj felett.

- Húzás alatt ( $1000 \mathrm{ml}$ súly vagy combhoz ragasztás feszítés alatt), de húzás nélkül is ugyanolyan a hatékonyság.

- A katéter kilökődéséig, de max. 12 óra.

Ellenjavallt: mélyen fekvő lepénynél, burokrepedés után, illetve ha közben burokrepedés történik, eltávolítandó.

GBS-pozitivitás esetén álló burok mellett nem ellenjavallt.

Dilapan (laminaria) 6-8 óra. 


\section{1. függelék folyt.}

\section{Burokrepesztés}

- Korai burokrepesztés (méhszáj 2-3 cm) és késői burokrepesztés (méhszáj >4-5 cm, a szülés aktív szakának elindulása után): a császármetszésarány ugyanolyan, az indukciótól a szülésig eltelt idő 5 órával kevesebb korai burokrepesztés esetén.

- Rögzült koponya vagy szükség esetén külsőleg rögzített koponya mellett, előtte elöl fekvő köldökzsinór vagy vasa praevia kizárandó, előtte és utána CTG-regisztrálás, időzítése szabad mútő mellett.

\section{Oxitocinos infúzió}

- Burokrepesztés nélkül kevésbé hatékony, mint burokrepesztés után, így burokrepedés elôtt inkább csak átmeneti ideig, a burokrepesztés feltételének elősegítésére.

- Burokrepesztés után azonnali oxitocinos infúzió vagy késleltetett infúzió is alkalmazható. A túl hosszú várakozás kedvezőtlen (elhúzódó szülés, felszálló infekció stb.). Ha kontrakciók spontán nem indulnak 4 órán belül, legkésőbb akkor oxitocinos infúzió javasolt.

- Spontán burokrepedés méhtevékenység indulása előtt terminusban (prelabour rupture of membranes, PROM): ha spontán kontrakciók max. 6-12 óra alatt nem indulnak, indukció: prosztaglandin (Bishop-score $\leq 5$-nél jön szóba) vagy oxitocinos infúzió. (Hosszabb várakozás a várhatóan 12-18 órával a burokrepedés után történő szülés miatt a felszálló infekció lehetőségére tekintettel nem javasolt, továbbá azért sem, mert ezek a szülőnők Magyarországon az érvényes irányelv szerint szülőszobai ellátást igényelnek, nem pedig otthon várakoznak, mint például Angliában.)

- Koraterhességi PROM (preterm PROM, PPROM): ellátásuk speciális megfontolásokat igényel a koraszülöttség miatt.

- $5 \mathrm{NE}$ oxitocin/500 ml Ringer-laktát inf. $25 \mathrm{ml} / \mathrm{h}$ kezdő dózissal, legkorábban 30 percenként emelve max. $25 \mathrm{ml} / \mathrm{h}$-val, a rendszeres, 2-3 perces kp. méhtevékenységig. Ezt bármely dózisnál (!) elérve további emelés nem javít a kimenetelen, csak uterus-hiperstimulációt okoz (tachysystole: $>5$ kontrakció/10 perc; hypertonia: $\geq 2$ perces kontrakció/kontraktúra).

- Prosztaglandin után min. 6 óra teljen el burokrepesztés vagy oxitocinos infúzióig a hiperstimuláció megelőzésére.

****A szülés latens fázisát a lassú cervixprogresszió és max. $4 \mathrm{~cm}$ (2 ujjnyi) cervixstatus jelzi. Ha a szülés kontrakciók hatására az aktív fázisba lép [méhszáj $\geq 5 \mathrm{~cm}$ (+ 2 ujjnyi)], akkor sikertelenség esetén már nem „sikertelen szülésindukció”, hanem „elakadt szülés” (téraránytalanság, fájásgyengeség, „failure to progress” stb.) a diagnózis.

*****Bármelyik utat választjuk, a gravidával közösen döntsünk, az ő részletes tájékoztatása és beleegyezése szükséges, de ebben az esetben figyelembe is kell venni az ő döntését. Ezt a kórlapban írásban dokumentáljuk 1-2 mondatban, és a gravida is írja alá.

Halasztott szülésindukció („postponed inducton”): ha 1 prosztaglandin után 24 óra elteltével nincs méhtevékenység, nincs cervixprogresszió, és áll a burok, alternatív lehetőség l alkalommal az indukció elhalasztása. Legkorábban 3 nap múlva, de legkésőbb a 41. hét betöltésekor az akkori friss Bishop-score-tól függő módon a szülésindukció újrakezdhető. Ilyenkor nem sikertelen szülésindukcióról („failed induction”) beszélünk, ez önmagában nem indikáció császármetszés végzésére. A halasztott indukció szintén a gravidával közös, írásban dokumentált döntés kell, hogy legyen. A halasztott indukcióig a rutin magzati és anyai állapotdiagnosztika folytatódik.

\section{Néhány adat, tudnivaló még a szülésindukciókkal kapcsolatban}

1) Az indukciók latens fázisának hosszabb volta azért szükséges, hogy az uterus oxitocinérzékenysége (oxitocinreceptor- és 'gap junction' expresszió) fokozódjon, emiatt kell türelmesnek lenni. Ugyanakkor tartós oxitocinos infúzió adásakor az uterus oxitocin iránti részleges deszenzitizációját is leírták, in vitro receptorexpresszió-csökkenést is kimutattak egyes vizsgálatok. Emiatt az infúzió átmeneti „pihentetésének” lehet némi létjogosultsága (egyes vizsgálatok 12 óra oxitocinos infúzió adása után javasolják, ha sikerült elérni az aktív fázist), bár egyértelmű előnyéről evidencia nem nagyon van. Ekkor az oxitocinos infúzió kb. 6 óra adása után 6-12 óra „pihentetés" szóba jöhet, antibiotikumvédelem mellett. Ha a latens fázis alatt alkalmazzuk, a kontrakciók általában jelentősen renyhülnek és ritkulnak, akár le is állnak. Ezért ezt az időintervallumot nem számítjuk be, amikor a sikertelen szülésindukció diagnózisát felállítjuk.

2) Oxitocinos infúzió hatására kialakuló rendszeres, közepes intenzitású kontrakciók mellett változatlanul latens fázisban levő szülésnél beavatkozást az irányelvek max. 12-15 óráig nem javasolnak. A 3 óráig tartó latens fázishoz képest a chorioamnionitis, post partum vérzés, emiatti transzfúzió, illetve az újszülött állapotára vonatkozó kedvezőtlen kimenetel összesített mutatója (composite adverse neonatal outcome) relatív kockázata 12, illetve 15 óráig engedett latens fázis után rendre a következők: 1,86 - 1,81 - 1,90 1,33, illetve 2,28 - 2,21 -2,35-1,47. Emiatt javasoljuk a sikertelen szülésindukció diagnózisának kimondásához mi is a legalább 12 órás várakozást, de 15 óránál semmiképpen ne többet, ha rendszeres kontrakciókkal nem jutott az aktív fázisba a szülés. A vajúdók 93\%-a 12 óránál rövidebb idő alatt jut a latens fázisból az aktív fázisba, 15 óránál rövidebb idő alatt pedig 96\%, viszont a 12-15 óra közötti idősávban aktív fázisba jutók 40\%-a még utána spontán szül.

3) A szülésindukció során korán (méhszáj $<4 \mathrm{~cm}$ ) alkalmazott epiduralis anesztéziának nincs kedvezőtlen hatása: nem több a császármetszés, hüvelyi szülésbefejező mútét, vagy nem rosszabb a neonatalis kimenetel.

4) A ballon + oxitocinos infúzió és ballon + prosztaglandin kombináció nem jobb, mint a ballon önállóan. Ballon vagy prosztaglandin vagy laminaria összehasonlításban egyforma a hatékonyság, a császármetszés-frekvencia. Mechanikus módszer alkalmazásakor kevesebb az uterus-hiperstimuláció.

CTG = kardiotokográfia; NST = nonstresszteszt; PROM = spontán burokrepedés méhtevékenység indulása előtt terminusban; TOLAC = hüvelyi szülés kísérlete előzetes császármetszés után 
2. függelék |A szülés módjának megválasztása előzményi császármetszés után

(DE KK Szülészeti és Nőgyógyászati Klinika, 2020. 06. 01.)

\section{Az alábbi kockázati tényezők közül fennáll-e bármelyik?}

- Előzményi méhrepedés

- Jelentős uterusrekonstrukciós mútét (transcervicalis septumresectio [TCRS] önmagában nem!)

- Előzményi vertikális vagy fordított „T" metszés a méhen

- Hüvelyi szülést kontraindikáló tényező (például placenta praevia, atípusos hosszfekvés stb.)

- $\geq 2$ császármetszés az előzményben

- Előző császármetszés <12 hónapja
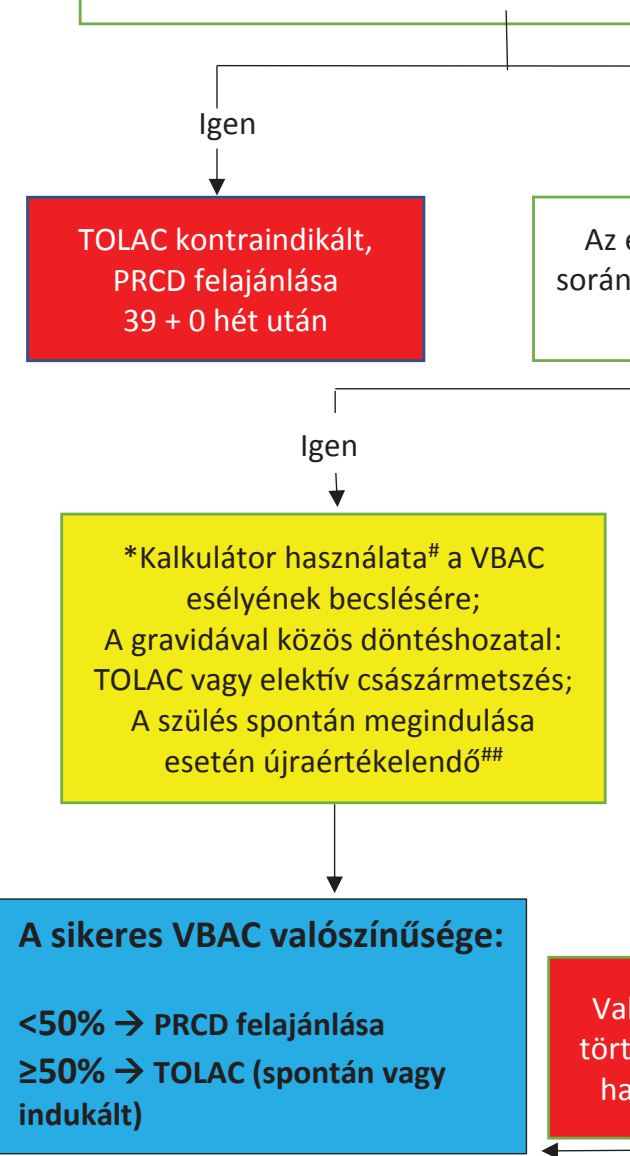

Az előzményi császármetszés orán alsó harántmetszés történt a méhen?

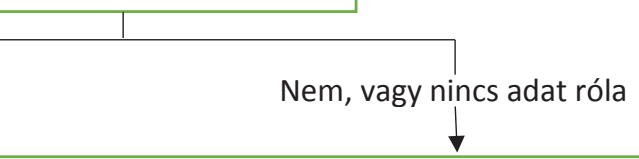

Volt-e olyan tényező, amely növeli a korábbi vertikális metszés esélyét?

- Extrém koraszülés (<28. hét)

- A méh alsó szegmentumát érintő olyan anatómiai rendellenesség, mely nem teszi lehetővé a harántmetszést (például nagy myoma a passzív szakaszon)

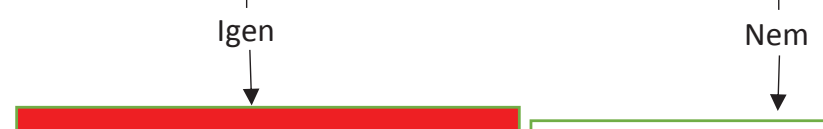

Valószínúleg vertikális metszés történt; császármetszés javasolt, ha nincs korábbi mútéti leírás
*A szülés módjáról a döntést a gravida az orvossal közösen hozza meg. Ennek a döntésnek az elérhető legjobb evidenciákon kell alapulnia, több tényező figyelembevételével:

- A sikeres VBAC \%-os esélye

- A TOLAC és az elektív császármetszés komplikációinak esélye és súlyossága, egyéni kockázatbecsléssel

- Személyes preferenciák, elvárások, korábbi szülésélmények és jövőbeli terhességre vonatkozó tervek szem előtt tartása

\#VBAC-kalkulátor a terhesgondozás során (metrikus):

- OmniCalculator: https://www.omnicalculator.com/health/vbac-risk-score

- UpToDate calculator: https://www.uptodate.com/contents/calculator-trial-of-labor-after-cesarean-tolac-foruse-at-entry-to-prenatal-care

\#"VBAC-kalkulátor a szülés megindulásakor (metrikus):

- UpToDate calculator: https://www.uptodate.com/contents/calculator-trial-of-labor-after-cesarean-tolac-foruse-at-the-time-of-admission-for-delivery
VBAC: hüvelyi szülés császármetszést követően (vaginal birth after cesarean) TOLAC: hüvelyi szülés kísérlete előzetes császármetszés után (trial of labour after cesarean)

PRCD: tervezett ismételt császármetszés (planned repeat cesarean delivery) 


\section{Köszönetnyilvánítás}

Köszönet illeti a Debreceni Egyetem, Klinikai Központ, Szülészeti és Nőgyógyászati Klinika, a Neonatalis Intenzív Centrum és Neonatológiai Osztály összes dolgozóját. A közleményben bemutatott eredmények csak a közös munkánkkal jöhettek létre.

\section{Irodalom}

[1] Grobman WA, Rice MM, Reddy UM, et al. Labor induction versus expectant management in low-risk nulliparous women. $\mathrm{N}$ Engl J Med. 2018; 379: 513-523.

[2] Middleton P, Shepherd E, Crowther CA, et al. Induction of labour for improving birth outcomes for women at or beyond term. Cochrane Database Syst Rev. 2018; 5: CD004945.

[3] Keulen JK, Bruinsma A, Kortekaas JC, et al. Induction of labour at 41 weeks versus expectant management until 42 weeks (INDEX): multicentre, randomised non-inferiority trial. BMJ 2019; 364: 1344 .

[4] Wennerholm UB, Saltvedt S, Wessberg A, et al. Induction of labour at 41 weeks versus expectant management and induction of labour at 42 weeks (SWEdish Post-term Induction Study, SWEPIS): multicentre, open label, randomised, superiority trial. BMJ 2019; 367: 16131

[5] Dekker R, Bertone A. Evidence on: inducing for due dates. 24 02. 2020. Available from: https://evidencebasedbirth.com/evidence-on-inducing-labor-for-going-past-your-due-date/ [accessed: February 14, 2021].

[6] American College of Obstetricians and Gynecologists. Practice advisory. Clinical guidance for integration of the findings of the ARRIVE trial: labor induction versus expectant management in low-risk nulliparous women. ACOG, August 2018. Available from: https://www.acog.org/Clinical-Guidance-and-Publications/Practice-Advisories/Practice-Advisory-Clinical-guidancefor-integration-of-the-findings-of-The-ARRIVE-Trial [accessed: March 1, 2021].

[7] Society of Maternal-Fetal (SMFM) Publications Committee. SMFM statement on elective induction of labor in low-risk nulliparous women at term: the ARRIVE trial. Am J Obstet Gynecol. 2019; 221: B2-B4.

[8] Papp Z. Induction of labour. In: Papp Z. The textbook of obstetrics and gynecology. [Szülésmegindítás. In: Papp Z. A szülészet-nőgyógyászat tankönyve.] Semmelweis Kiadó, Budapest, 2017; pp. 418-420. [Hungarian]

[9] Nagy Gy. Post-term pregnacy. Cervical ripening. In: Papp Z. (ed.) Protocols in obstetrics and gynecology. [Túlhordás. A méhszáj érlelése. In: Papp Z. (szerk.) Szülészet-nőgyógyászati protokoll.] Golden Book Kiadó, Budapest, 1999; pp. 395-397. [Hungarian]

[10] Hungarian College of Obstetricians and Gynecologists. Ministry of Health protocol of labour induction. [Szülészeti és Nőgyógyászati Szakmai Kollégium. Az Egészségügyi Minisztérium szakmai protokollja a szülésindukcióról.] Eü Közlöny 2008; 58: 1534-1539. [Hungarian]

[11] Palatnik A, Grobman WA. Induction of labor versus expectant management for women with a prior cesarean delivery. Am J Obstet Gybecol. 2015; 212: 358.el-e6.

[12] ACOG. Practice Bulletin No. 205. Vaginal birth after cesarean delivery. Obstet Gynecol. 2019; 133: el10-e127.

[13] Dy J, DeMeester S, Lipworth H, et al. SOGC Clinical practice guideline No. 382-Trial of labour after caesarean. J Obstet Gynaecol Can. 2019; 41: 992-1011. [Erratum: J Obstet Gynaecol Can. 2019; 41: 1395.] [Erratum: J Obstet Gynaecol Can. 2020; 42: 1452.]

[14] Metz TD. Choosing the route of delivery after cesarean birth. UpToDate, March 2020. Available from: https://www.uptodate.com/contents/choosing-the-route-of-delivery-after-cesar- ean-birth? search=Choosing $\% 20$ the $\% 20$ route $\% 20$ of $\% 20$ delivery $\% 20$ after $\% 20$ cesarean $\% 20$ birth\&source=search_result\&select edTitle $=1 \sim 150 \&$ usage_type $=$ default $\&$ display_rank=1 [accessed: March 30, 2020].

[15] Grobman W. Cervical ripening and induction of labor in women with a prior cesarean delivery. UpToDate, March 2020. Available from: https://www.uptodate.com/contents/cervical-ripeningand-induction-of-labor-in-women-with-a-prior-cesarean-delivery? search $=$ Cervical $\% 2$ ripening $\% 20$ and $\% 20$ induction $\% 20$ of $\% 20$ labor $\% 20 \mathrm{in} \% 20$ women $\% 20$ with $\% 20$ a $\% 20$ prior $\% 20$ cesarean\&source $=$ search_result \&selectedTitle $=1 \sim 150 \&$ usage_ type=default\&display_rank=1 [accessed: March 30, 2020].

[16] National Institute for Health and Care Excellence. NICE Guideline. Induction of labor. July 2008. Available from: https:// www.nice.org.uk/guidance/cg70/evidence/cg70-inductionof-labour-full-guideline 2 [accessed: 30. 03. 2020].

[17] National Institute for Health and Care Excellence. NICE Guideline. Inducing labor - Quality standard. 17. 04. 2014. Available from: https://www.nice.org.uk/guidance/qs60 [accessed: March 30, 2020].

[18] Royal College of Obstetricians and Gynecologists. Birth after previous caesarean birth (Greentop guideline No. 45). RCOG, 01. 10. 2015. Available from: https://www.rcog.org.uk/en/ guidelines-research-services/guidelines/gtg45/ [accessed: March 30, 2020].

[19] ACOG. Practice Bulletin No. 115. Vaginal birth after previous cesarean delivery. Obstet Gynecol. 2010; 116(2 Pt 1): 450-463.

[20] ACOG. Practice Bulletin No. 107. Induction of labor. Obstet Gynecol. 2009; 114(2 Pt 1): 386-397.

[21] Grobman WA. Induction of labor: Techniques for preinduction cervical ripening. UpToDate, March 2020. Available from: https://www.uptodate.com/contents/induction-of-labortechniques-for-preinduction-cervical-ripening? search=Techniques $\% 20$ for $\% 20$ ripening $\% 20$ the $\% 20$ unfavorable $\% 20$ cervix $\% 20$ prior $\% 20$ to $\% 20$ induction \&source $=$ search_result\&selectedTitle $=$ 1 150\&usage_type=default\&display_rank=1 [accessed: March $11,2020]$.

[22] Gobman WA. Induction of labor with oxytocin. UpToDate, March 2020. Available from: https://www.uptodate.com/contents/induction-of-labor-with-oxytocin?search=Induction $\% 20$ of $\% 20$ labor\%20with\%20 oxytocin\&source=search_result\&selecte dTitle $=1 \sim 150 \&$ usage_type $=$ default $\&$ display_rank=1 $\quad$ accessed: March 10, 2020].

[23] Grant GJ. Adverse effects of neuraxial analgesia and anesthesia for obstetrics. UpToDate, March 2020. Available from: https:// www.uptodate.com/contents/adverse-effects-of-neuraxial-analgesia-and-anesthesia-for-obstetrics?search=Adverse $\% 20 \mathrm{ef}$ fects $\% 20$ of $\% 20$ neuraxial $\% 20$ analgesia $\% 20$ and $\% 20$ anesthesia $\% 20$ for $\% 20$ obstetrics \&source $=$ search_result \&selected Title $=1 \sim 150 \&$ usage_type $=$ default\&display_rank=1 [accessed: February 28, 2020].

[24] Grobman WA, Bailit J, Lai Y, et al. Defining failed induction of labor. Am J Obstet Gynecol. 2018; 218: 122.el-122.e8.

[25] Csákány MGy. Personal communication. Obstetrical data of the Tauffer statistics. [Személyes közlés. A Tauffer szülészeti statisztika adatai.] Budapest, March 2021.

[26] Arnaez J, Ochoa-Sangrador C, Caserío S, et al. Lack of changes in preterm delivery and stillbirths during COVID-19 lockdown in a European region. Eur J Pediatr. 2021 Feb 12. Doi: 10.1007/ s00431-021-03984-6. [Epub ahead of print]

[27] Wood R, Sinnott C, Goldfarb I, et al. Preterm birth during the coronavirus disease 2019 (COVID-19) pandemic in a large hospital system in the United States. Obstet Gynecol. 2021; 137: 403-404

[28] Philip RK, Purtill H, Reidy E, et al. Unprecedented reduction in births of very low birthweight (VLBW) and extremely low birthweight (ELBW) infants during the COVID-19 lockdown in Ire- 
land: a 'natural experiment' allowing analysis of data from the prior two decades. BMJ Glob Health 2020; 5: e003075.

[29] Hedermann G, Hedley PL, Baekvad-Hansen M, et al. Danish premature birth rates during the COVID-19 lockdown. Arch Dis Child Fetal Neonatal Ed. 2021; 106: 93-95.

[30] Molina G, Weiser TG, Lipsitz SR, et al. Relationship between cesarean delivery rate and maternal and neonatal mortality. JAMA 2015; 314: 2263-2270.

[31] Ye J, Zhang J, Mikolajczyk R, et al. Association between rates of caesarean section and maternal and neonatal mortality in the 21st century: a worldwide population-based ecological study with longitudinal data. BJOG 2016; 123: 745-753.
[32] Volpe FM. Correlation of cesarean rates to maternal and infant mortality rates: an ecologic study of official international data. Rev Panam Salud Publica 2011; 29: 303-308.

[33] Papp Z. Causas of increase of cesarean delivery rate during the last years. [A császármetszési arány emelkedésének okai az utóbbi években.] 19. 07. 2018. Available from: https://maternity. hu/a-csaszarmetszesi-arany-emelkedesenek-okai-az-utobbievekben/ [accessed: February 21, 2021].

(Deli Tamás dr., Debrecen, Nagyerdei krt. 98., 4032 e-mail: tamasdeli@yahoo.com)

\section{PÁLYÁZAT}

Kömlőd Község Önkormányzata (2853. Kömlöd, Szabadság u. 9.) pályázatot ír ki Kömlőd vegyes körzet háziorvosi feladatainak területi ellátási kötelezettséggel történő ellátására.

Munkavégzés helye: Kömlőd, Kömlőd, Pálóczi Horváth Á. u. 21.

Ellátandó feladat: A 4/2000. (II. 25.) EüM rendeletben foglalt háziorvosi feladatok ellátása, - területi ellátási kötelezettséggel, - vállalkozási formában - önkormányzattal kötött feladatellátási szerződés szerint.

Pályázati feltételek:

- egyetemi végzettség,

- a 4/2000. (II. 25.) EüM rendeletben foglalt képesítési feltételek megléte,

- szakmai alkalmassági orvosi vélemény,

- büntetlen előélet,

- B” kategóriás jogosítvány.

A pályázat részeként benyújtandó iratok, igazolások:

- orvosi diploma, valamint a szakképzettséget igazoló diploma másolata,

- 3 hónapnál nem régebbi erkölcsi bizonyítvány,

- részletes szakmai önéletrajz,

- jogosítvány másolata,

- vállalkozás meglétét igazoló dokumentumok másolata,

- egészségügyi alkalmasság igazolása,

- magyar orvosi kamarai tagsági igazolás,

- a pályázó nyilatkozata arról, hogy a pályázati anyagban foglalt személyes adatainak a pályázati eljárással összefüggő kezeléséhez hozzájárul,

- a pályázó nyilatkozata arról, hogy nyilvános vagy zárt ülés keretében kéri a pályázat elbírálását.

A pályázat beadásának határideje: Az Eü Közlönyben történő megjelenéstől számított 30 napon belül.

A pályázat elbírálásának határideje: A pályázatot Kömlőd Község Önkormányzat képviselő-testülete bírálja el, a pályázati határidő lejártát követö ülésen.

Az álláshely betölthető: A pályázatok elbírálása után.

A pályázat benyújtása: Zárt borítékban „Pályázat Kömlőd vegyes háziorvosi munkakör betöltésére” megjelöléssel, postai úton: a Kömlőd Község Önkormányzata címére történő megküldéssel (2853. Kömlőd, Szabadság u. 9).

Személyesen: Dadi Közös Önkormányzati Hivatal Kömlődi Kirendeltségén, (2853. Kömlőd, Szabadság u. 9).

Egyéb információk:

- szabad orvosi praxis,

- lehetőség a 12 hónapja betöltetlen háziorvosi körzeteket betöltő háziorvosok letelepedésének támogatására kiirt pályázat benyújtására.

- jól felszerelt rendelőt, gyakorlott asszisztenciát, tudunk biztosítani.

- az álláshelyről felvilágositást nyújt Bogáth István polgármester a 06-30-604-3188-as telefonszámon.

- a képviselő -testület fenntartja magának a jogot, hogy a pályázatot indokolás nélkül eredménytelennek nyilvánítsa.

Schvarczné Stieber Rita aljegyző

A cikk a Creative Commons Attribution 4.0 International License (https://creativecommons.org/licenses/by/4.0/) feltételei szerint publikált Open Access közlemény, melynek szellemében a cikk bármilyen médiumban szabadon felhasználható, megosztható és újraközölhetö, feltéve, hogy az eredeti szerző és a közlés helye, illetve a CC License linkje és az esetlegesen végrehajtott módositások feltüntetésre kerülnek. (SID_1) 